\title{
Paleoseismology of the southwestern Morelia-Acambay fault system, central Mexico
}

\author{
V. H. Garduño-Monroy ${ }^{1 *}$, R. Pérez-Lopez², I. Israde-Alcantara ${ }^{1}$, M. A. Rodríguez-Pascua², E. Szynka- \\ ruk $^{3}$, V. M. Hernández-Madrigal ${ }^{1}$, M. L.García-Zepeda ${ }^{4}$, P. Corona-Chávez ${ }^{1}$, M. Ostroumov ${ }^{1}$, V. H. \\ Medina-Vega ${ }^{1,5}$, G. García-Estrada ${ }^{6}$, O. Carranza ${ }^{7}$, E. Lopez-Granados ${ }^{1}$ and J. C. Mora Chaparro ${ }^{8}$ \\ ${ }^{1}$ Instituto de Investigaciones Metalurgicas, Universidad Michoacana de San Nicolás Hidalgo, Cuerpo Académico Consolidado de \\ Ciencias de la Tierra, Ciudad Universitaria, Morelia, Michoacán, Mexico \\ ${ }^{2}$ Servicio Geológico y Minero de España, Madrid, Spain \\ ${ }^{3}$ Posgrado en Ciencias de la Tierra, Instituto de Geofisica, Universidad Nacional Autónoma de México, Mexico City, Mexico \\ ${ }^{4}$ Facultad de Biología, Universidad Michoacana de San Nicolás Hidalgo, Ciudad Universitaria, Morelia, Michoacán, Mexico \\ ${ }^{5}$ Maestria en Geociencias y Planificación del Territorio-Instituto de Investigaciones Metalurgicas, Universidad Michoacana de \\ San Nicolás Hidalgo, Ciudad Universitaria, Morelia, Michoacán, Mexico \\ ${ }^{6}$ Gerencia de Proyectos Geotermoelectricos, Comisión Federal de Electricidad \\ ${ }^{7}$ Geociencias de Juriquilla, Universidad Nacional Autónoma de México, Juriquilla, Querétaro, Mexico \\ ${ }^{8}$ Departamento de Vulcanología, Instituto de Geofísica, Universidad Nacional Autónoma de México, Mexico City, Mexico
}

Received: November 7, 2007; accepted: April 1, 2009

\section{Resumen}

El sistema de fallas Morelia-Acambay (MAFS) consiste en una serie de fallas normales de dirección E-W y NE-SW que cortan la parte central del Cinturón Volcánico Transmexicano. El sistema de fallas se asocia a la formación de las depresiones lacustres de Chapala, Zacapu, Cuitzeo, Maravatio y Acambay. Las fallas E-W de MAFS aparecieron hace 7-9 millones de años durante Mioceno temprano. Las fallas NNW-SSE son más viejas y se han reactivado en el tiempo, desplazando y controlando a las depresiones lacustres E-W.

Se estimaron las magnitudes sísmicas de las estructuras E-W de la región de Morelia-Cuitzeo asumiendo una ruptura cosismica. Cartografía, geología estructural y paleosismología sugieren que las estructuras de MAFS en la región de Morelia-Cuitzeo han estado activas durante el Holoceno, controlando los terremotos históricos que afectan a paleosuelos con cerámica de las culturas Pirinda-Purepecha. Estos terremotos históricos también están registrados en las fallas E-W del campo geotérmico de Los Azufres. En la región de Pátzcuaro, las estructuras E-W de MAFS también se ligan a sismos fuertes ocurridos durante épocas prehistóricas e históricas. Por ejemplo, la secuencia lacustre de Jarácuaro, en el sector meridional del lago Pátzcuaro ha registrado por lo menos tres sismos importantes (Período de PostClassic, 1845 y 1858). El sismo de 1858 (Magnitud estimada de 7.3) generó un tsunami de $2 \mathrm{~m}$ de altura descrito en los archivos históricos. Un sismo similar en la actualidad devastaría esta zona del estado de Michoac'an, la cual está ocupada por las poblaciones de más alta densidad. De hecho, el 17 de octubre de 2007 mientras que este articulo era escrito, ocurrieron tres sismos en la ciudad de Morelia que fueron ligados a la falla normal derecha de la Central o de La Paloma. Este hecho corroboraba la sismicidad potencial de las fallas E-W y NE-SW del TMBV.

Palabras clave: Sismicidad, Morelia, Tectónica activa, fallas normales, Cuitzeo.

\section{Abstract}

Fr The Morelia-Acambay Fault System (MAFS) consists of a sequence of E-W and NNE-SSW trending normal faults within the Trans-Mexican Volcanic Belt. The fault system is associated to the Chapala, Zacapu, Cuitzeo, Maravatio and Acambay lacustrine depressions. The E-W faults of MAFS appear to be 7-9 million yr old while the NNW-SSE faults are older and were reactivated producing stepped east-west geometry with a transtensional-right hand deformation.

Seismic magnitudes of the E-W structures in the Morelia-Cuitzeo region are estimated. Cartography, structural geology, and trench stratigraphy of these faults suggest Holocene activity. Historical earthquakes disrupted paleosols containing Pirinda-Purepecha shards. These Historical earthquakes are also imprinted in seisms along E-W faults at Los Azufres geothermal field. In the Patzcuaro region, the E-W structures are also linked to strong seismic events occurred during prehistoric and historical times. The Jaracuaro lacustrine sequence in the southern Patzcuaro Lake contains evidence at least three important earthquakes (PostClassic, 1845 and 1858) and a possible tsunami associated to the 1858 event. The magnitude of this earthquake was estimated at $~ 7.3$. An earthquake of this magnitude would damage a density populated area of Michoacán State. On October 17, 2007, three small earthquakes were felt in Morelia associated to normal E-W fault mechanisms of Central Camionera Fault corroborating the seismic potential of MAFS in the TMBV.

Key words: Seismicity, Morelia, Active Tectonic, normal fault, Cuitzeo. 


\section{Introduction}

The Morelia-Acambay fault system (MAFS) is an E-W structure in the Trans-Mexican Volcanic Belt (TMVB), in the central part of the Chapala-Tula Fault zone (Johnson and Harrison, 1989). Previous studies report that the E-W fault system in the central part of the TMVB is seismically active (Quintero-Legorreta et al., 1988; Suter et al., 1992; Ramírez-Herrera, 1996; Suter et al., 1995b; GarduñoMonroy et al., 1997; Garduño-Monroy and Escamilla, 1996; Garduño-Monroy et al., 2001, García-Palomo et al., 2000, (Suter et al., 2001). Recurrence periods on these faults are unknown. For the Acambay fault in the eastern part of the system, a recurrence interval of $3600 \mathrm{yr}$ was proposed (Langridge et al., 2000). There is a connection between this tectonic system and the seismicity, in the Araro zone and the El Chino fault at Los Azufres geothermal field (Valdés-González and Pérez-Esquivias, 2007). Historical records contain a large number of events that might be related to the activity of MAFS. In the eighteenth century, several earthquakes were reported in1786 and1787 that cause damage inTlalpujahua, Araro and Zinapécuaro (Urquiza, 1872; Ramírez and Reyes, 1873). These earthquakes struck the gold and silver mines in Tlalpujahua (Flores, 1920). Earthquake repots in 1806, 1837, 1839, 1843, 1849, 1857, 1858, 1873, 1875, 1887, 1894 and 1895 for of Morelia, Tlalpujahua, Zinapécuaro, Queréndaro and Araro, included casualties (Garduño et. al., 1998; Suter et al., 1996; Suter et. al., 1995a-b). Most of the earthquake damage was concentrated along the E$\mathrm{W}$ fault segments of MAFS. Important earthquakes with hypocenters located between the towns of Acambay and Maravatío occurred in 1912, 1979 and 1998). The town of Acambay was partly destroyed by the 1912 event on the Acambay fault (Urbina and Camacho, 1913), Maravatio, had swarm activity in 1979 and 1998 on the Venta de Bravo fault (Astiz, 1980; UNAM, 1998), followed by some activity up to $\mathrm{Mg}=4$.

In this work we describe the western segment of MAFS, with special attention to the Morelia-CuitzeoZinapécuaro region. A review of the stratigraphy and structural geology of the region is first presented. Stratigraphic, paleontological and geochronological data provide new information on past earthquakes in the region, and morphology and length of the fault scarps, associated deposits, and paleoseismologic data provide new insights on the ongoing activity of the segment.

\section{Tectonic setting}

Three regional fault systems affect the central part of the TMVB; the older NW-SE to N-S trending faults of Basin and Range type; the NE-SW trending system; and the E-W MAFS faults, which are the subject of this study. The first two fault systems offset the MAFS (MartínezReyes and Nieto-Samaniego, 1990; Suter et al., 1992). All three fault systems are exposed over the study area, particularly in the vicinity of Morelia, which is located at the intersection of these systems (Fig. 1).

\section{The NW-SE fault system}

Regional extensional faulting in northern Mexico trends NW-SE to NNE-SSW and may belong to the Basin and Range province. The activity of these faults began $\sim 30 \mathrm{Ma}$ in the USA and northern Mexico (Henry and Aranda, 1992) and continues today. In the TMVB, these faults may be contemporaneous with the E-W extensional faults (Suter et al., 1995a). South of the TMVB (Tzitzio region), faults with this orientation have experienced mostly lateral movement (Mennella et al., 2000). The most important structure of this system is the Taxco-Querétaro fault zone (Demant, 1978; Demant, 1981; Pasquarè et. al., 1991; Garduño and Gutierrez, 1992; Ferrari et. al., 1994, Garcia-Palomo et al;, 2000). Other faults with similar orientation appear in the Maravatío-Ciudad Hidalgo depression (Fig. 1), to the E and SE of Morelia and in the vicinity of Indaparapeo (Fig. 2).

Near Morelia, a NW-SE fault cuts the Miocene andesite at Sierra de Mil Cumbres. These rocks are overlain by a $12 \mathrm{Ma}$. Morelia ignimbrites originated at the Atécuaro caldera (M. Suter, 2001, personal communication, Garduño et al., 1999b). Río Chiquito River follows the NW-SE oriented faults with a $40 \mathrm{~m}$ drop at its SW bank (Fig. 2). Outcrops along an access road to the GuadalajaraMorelia highway south of Morelia reveal shear structures and semihorizontal and semivertical superimposed striate representing first right-lateral, and later, normal movements. Further east, in the vicinity of Indaparapeo and Atapaneo, NW-SE oriented faults form a small graben with surface drops of $\sim 20 \mathrm{~m}$. These faults cut lava flows, recent lacustrine sediments, and apparently, also E-W oriented faults (Fig. 2). Another NW-SE fault with a 500$\mathrm{m}$ surface drop exists between Los Azufres geothermal field and the Zinapécuaro area and the Cuitzeo Lake. East of the study area, in the vicinity of Temascalcingo, a series of NW oriented faults form grabens and half-grabens that displace the base of the present soil (unpublished data). Thus the NW-SE oriented faults may still be active as concluded by Suter et al. (1995a). The Tzitzio-Valle de Santiago regional fault that generated the Tzitzio fold displaces the Queréndaro-Indaparapeo lava flows dated at $700 \mathrm{ka}$ (Pradal and Robin, 1994). NW-SE faults generated $10 \mathrm{~km}$ long right-hand displacements in the Cuitzeo depression related to the Valle de Santiago volcanism as shown by morphological data (Fig. 3). Similar structures 


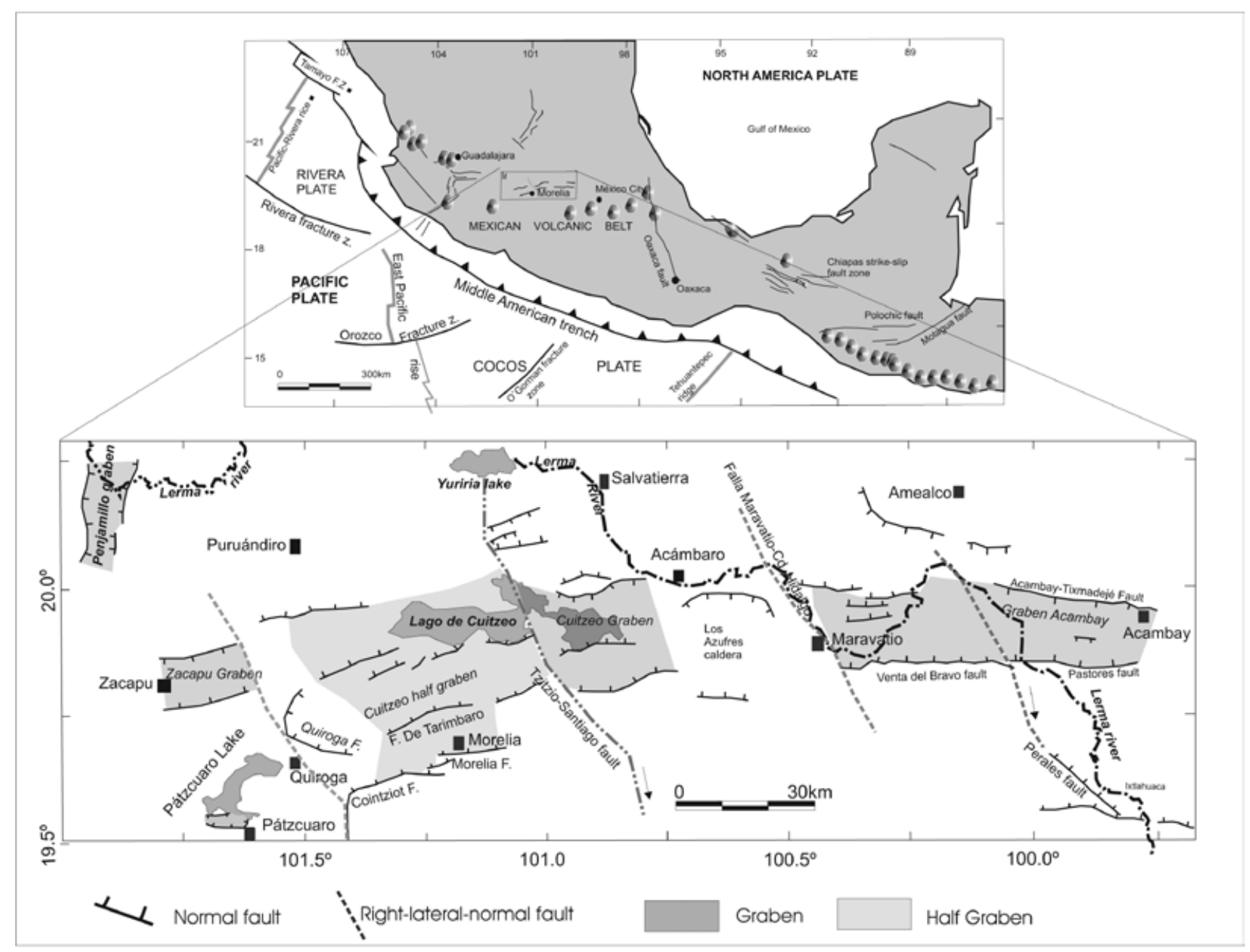

Fig.1. Regional tectonic setting between Pátzcuaro and Acambay including the city of Morelia.

have generated the west stepping geometry of the lacustrine depressions (Szynkaruk et al., 2004). Other regional structures include the Infiernillo-Penjamillo fault. In conclusion, that the NNW-SSE fault have been reactivated as right-lateral faults along the deformation tensor of the TMVB (Pasquare et al., 1997).

\section{The NE-SW fault system}

Regional NE-SW oriented faults were recognized in various locations of the central TMVB. Such faults might underlay Mexico City (Tenochtitlán shear zone De Cserna et al., 1988). They might reach the Apan region (García-Palomo et al., 2002). They may also be found near Nevado de Toluca volcano (García-Palomo et al., 2000). In the western portion of the study area and in the Michoacán-Guanajuato volcanic field, faults with this orientation are associated to alignments of cinder cones (Connor, 1990). This NE-SW structural trend separates the Chapala half-graben from the Cuitzeo half-graben by offsetting the position of their axes (Israde and Garduño, 1999; their Fig. 1) (Fig. 1). Aeromagnetic maps of the region (CRM, 1996, 1998) and the gravimetric data (M. Mena, 2002, personal communication) show NESW oriented alignments of magnetic and gravimetric anomalies in the western portion of the study region (Fig. 3 ). The older NNW-SSE trends may have been reactivated with a normal-right-hand movement (Fig. 1).

Locally, slip planes with NE-SW orientation are common throughout the MAFS (unpublished data). In the vicinity of Morelia, these faults have two generations of striae, the first one pitches $0-15^{\circ}$ with left-lateral movement, and the second one has semivertical striae with normal movement. These faults may date from $\sim 15 \mathrm{Ma}$ as left-lateral strike-slip faults, reactivated as normal faults in early Pliocene (Israde-Alcantara and Garduño-Monroy, 1999). A similar scenario has been inferred for the NE- 


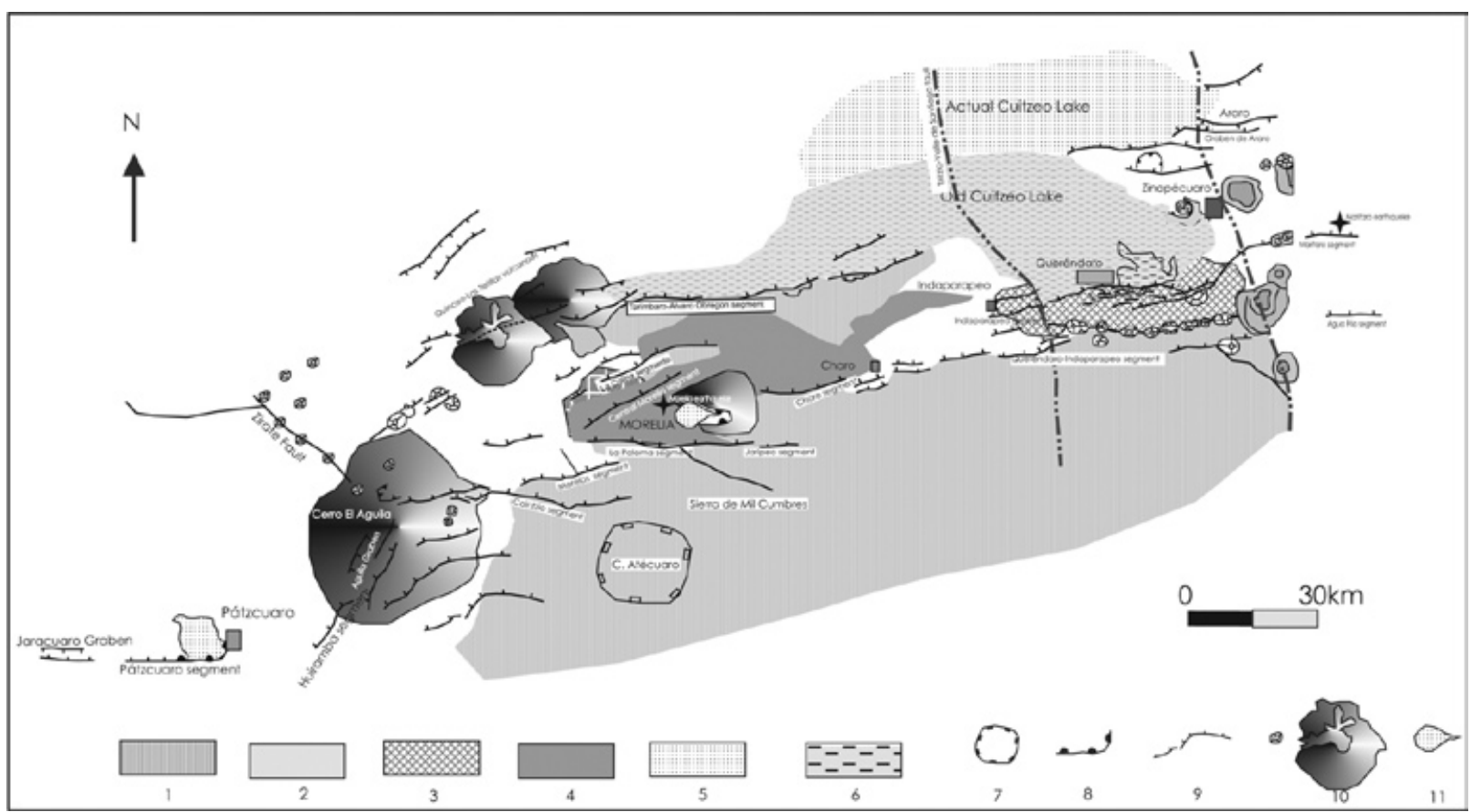

Fig. 2 Geologic and tectonic map of the study area. MAFS segments control the extent and distribution of volcanism and sedimentation in the area. Small faults with NW-SE and NE - SW orientations are also shown.: 1 and 2 - Rhyolitic domes of Los Azufres. 3 - Basaltic lava flows of Queréndaro dated $\sim 700 \mathrm{ka}$. 4- Miocene-Pliocene fluvio-lacustrine sequences. 5 - Limit of the ancient and present Cuitzeo Lake. 6 - Caldera structure. 7 - Collapse structure. 8 - Normal faults, 9 - Monogenetic cones and shield volcanoes. 10 - Landslide or pyroclastic flow deposits.

SW oriented faults in the Apan region (García-Palomo et al., 2002) and in the Mexico Basin (García-Palomo 2001, personal communication). Israde (1995) showed that the NE-SW oriented faults were highly active between 3-5 Ma when of the Morelia and Cuitzeo lacustrine basins were formed in response to extensional faulting.

\section{The MAFS fault system}

MAFS is the most seismically active system of the TMVB. In its western part, around Morelia, MAFS consists of two main faults with several segments that define a tectonic boundary between two distinct geologic provinces: to the north, the Plio-Quaternary active volcanism and fluvio-lacustrine sedimentation of the TMVB, and to the south, Miocene volcanic rocks of Sierra de Mil Cumbres that host silicic calderas (e.g. Atecuaro, La Escalera). MAFS comprises segments with seismic historic activity. The origin of these faults goes back to Late Miocene - Early Pleistocene, as E-W trending faults along the southern borders of the Miocene basins of Charo,
Maravatío and Venta de Bravo (Israde et. al., 1992; Israde, 1995; Israde and Garduño, 1999) (Fig.1). It caused the structural and morphological reorganization of the central and western parts of the TMVB with formation of fluviolacustrine basins and 200-m high fault scarps. At Morelia and Cuitzeo, MAFS structures show hanging walls to the north (Israde-Alcantara and Garduño-Monroy, 1999; Garduño et al., 1997; Israde, 1995; Johnson and Harrison, 1990) along as the southern edge of the lacustrine basins (Israde, 1995) (Fig. 1, 2). These faults have progressively tilted lake-beds toward the modern Cuitzeo Lake, a rotational movement of the MAFS fault system associated with listric faults. As in Chapala lake, west of the study area, MAFS faults at the southern edge of the Cuitzeo, Tarímbaro and Morelia depressions are more important than the corresponding northern bounding faults.

\section{Regional easth earthquakes related to MAFS}

The study area has experienced four types of seismic activity: (1) deep focus, subduction earthquakes, (2) 


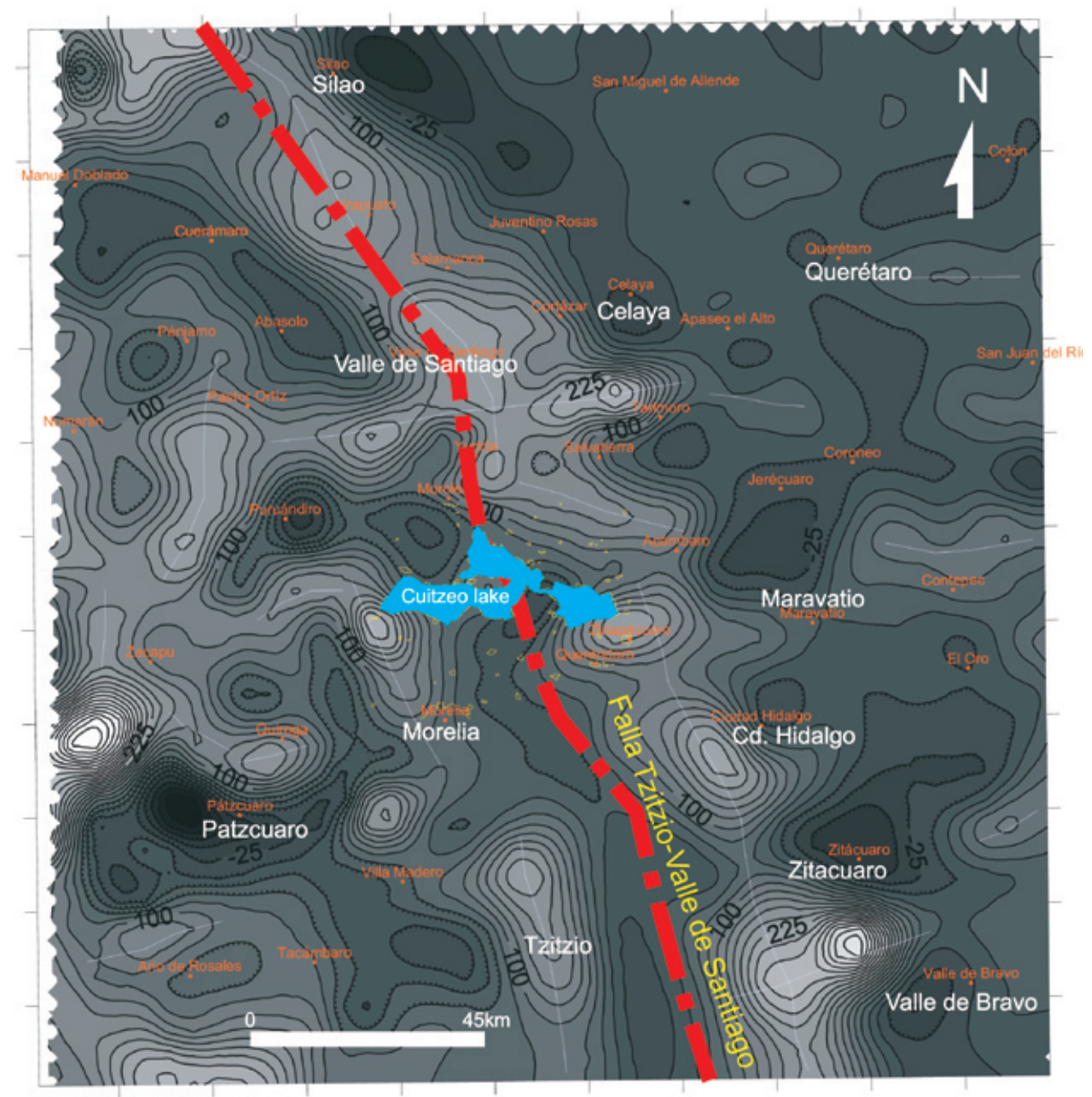

Fig. 3. Magnetic anomalies in the area (Servicio Geológico Mexicano). This map shows the anomalies of the Tztzio-Valle de Santiago fault.

intraplate, intermediate-depth, normal slab earthquakes, (3) intraplate, shallow, normal earthquakes (Singh et al., 1996), and (4) silent, slip earthquakes (Garduno-Monroy et al., 2000).

Subduction earthquakes occur along the Pacific coast. Large magnitude events are felt over broad areas of southern and central Mexico. These are the most destructive earthquakes experienced in Mexico, the 1985 earthquake that severely damaged Mexico City. The damage caused by these earthquakes is unrelated to MAFS.

Intraplate, intermediate earthquakes caused by normal faulting in the subducting slab are related to historical events. Two large earthquakes of this type may have occurred in 1845 and 1858 (Singh et al., 1996). The isoseismals of the 1858 earthquake by Figueroa (1974) assign a 7.0 of intensity and locate the epicenter in the Tarasco corridor nearby the site of Parícutin volcano $\left(19^{\circ} 39^{\prime} \mathrm{N}, \quad 102^{\circ} 11^{\prime} \mathrm{W}\right)$. This author estimated the Mercalli intensity of this event at IX in of Morelia and Pátzcuaro. Parts of Mexico City, Morelia, Pátzcuaro and Araro were damaged in this earthquake. In Araro, the cathedral was damaged (Garduño-Monroy et al., 1997). According to Sánchez-Garcilazo (2000) the 1845 and 1858 earthquakes, were caused by a similar mechanism. During both earthquakes, the Pátzcuaro area behaved as a high-intensity island (Singh et al., 1996). The isoseismals tend to parallel the MAFS structures in the area (Fig. 4A, B).

Paleoseismological studies around Jaracuaro south of Patzcuaro, sugest that at least two important earthquakes may have occurred during the last 10,000 years. A debris avalanche occurred after 28,000 yr ago plus volcanic activity during the last 8,000 yr. (Israde-Alcantara et al., 2005). 

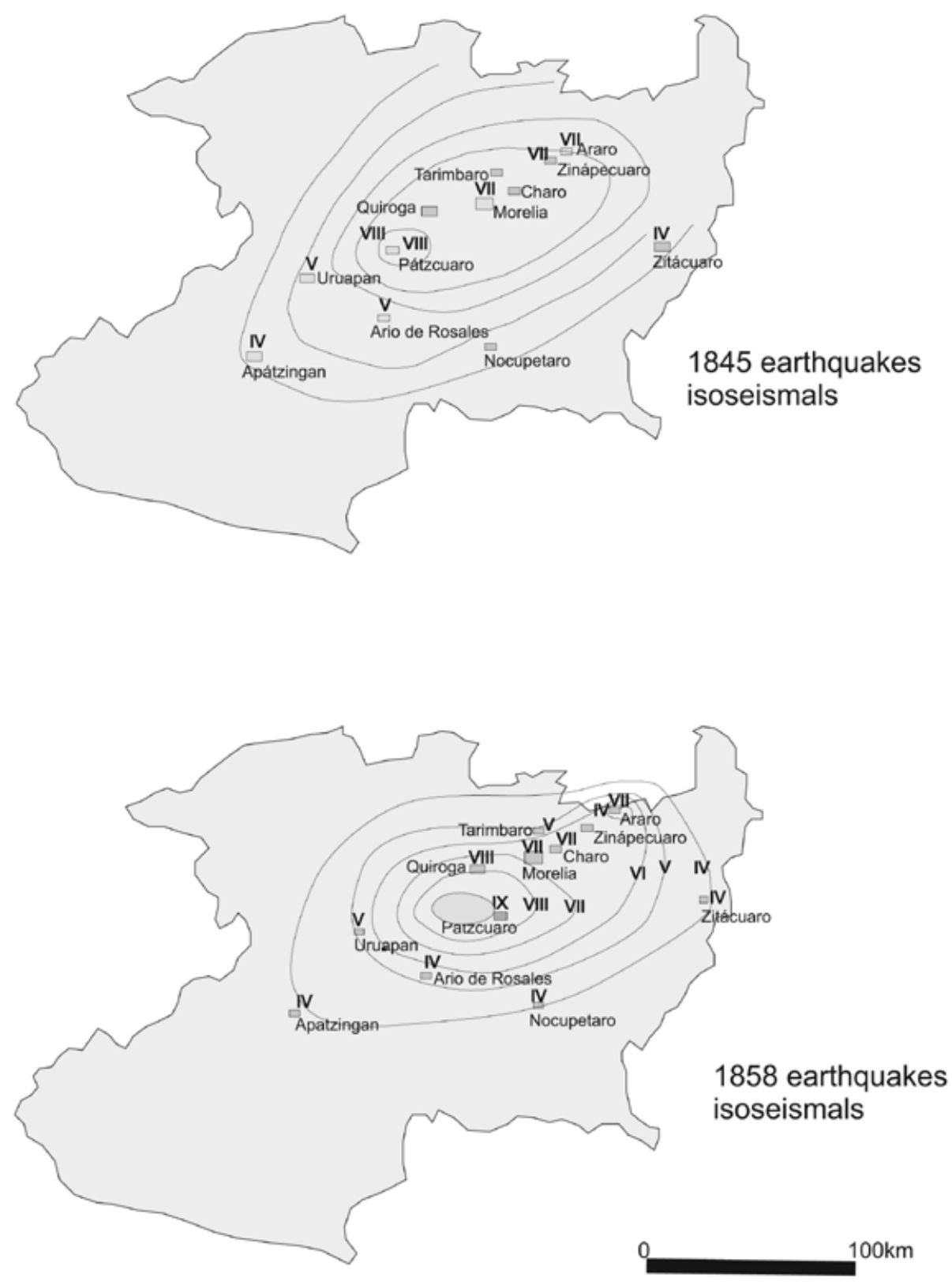

Fig. 4. Isoseismals of the 1845 (A) and 1858 (B) earthquakes. Pátzcuaro and Araro high intensity and substantial losses were reported. Morelia (population about 20,000) had a calculated intensity of VII.

The 1845 and 1858 epicenters fall within the area of maximum seismic and volcanic activity during the Pleistocene-Recent period (Garduño-Monroy, et. al., 2004).

Earthquakes directly related to normal faulting on MAFS structures include the events of 1912, 1979 and 1998. The Acambay earthquake of 1912, magnitude 6.7 ruptured the Acambay-Tixmadejé fault and several other minor faults in the Acambay graben partly destroying the town of Acambay (Urbina and Camacho, 1913). The February 1979 earthquake had a magnitude of 5.3 with an epicenter on the Venta de Bravo fault (Astiz, 1980). The June 1998, Maravatío swarm included nine events with magnitudes over 3 and epicenters at depths between 3-11 $\mathrm{km}$ on the Venta de Bravo fault. The focal mechanism of this earthquake consisted of N-S oriented extension with a small left-lateral component (Lermo-Samaniego, 1998, pers. com.). 


\section{Fault segments of the SW MAFS and their seismic potential}

MAFS contains by eight active normal fault segments, mainly oriented NE-SW or E-W, with a secondary striking to N-S (Fig. 2). The main orientation, surface length (SRL) and age of the youngest deposits affected by fault movements are summarized in the Table 1.

\section{Methodology for estimating earthquake magnitude}

We have applied the empirical relationships suggested by Wells and Coppersmith (1994) to calculate the moment magnitude $(\mathrm{Mw})$ from the surface rupture length (SRL),

$$
\mathrm{Mw}=\mathrm{a}+\mathrm{b}^{*} \log (\mathrm{SRL})
$$

where $\mathrm{a}=4.86$ and $\mathrm{b}=1.32$, for normal type faults (Wells and Coppersmith, 1994). This empirical relationship was obtained from 77 instrumental earthquakes of a worldwide database, with magnitudes ranging between 5.2 and 7.3, and SRL values ranging from 2.5 to $40 \mathrm{~km}$.

We have also applied the empirical regression formula suggested by Stirling et al. (2002). These authors suggested equation [1] with different values of the parameters: a $=5.45$ and $\mathrm{b}=0.95$ for instrumental earthquakes and $\mathrm{a}$ $=5.89$ and $\mathrm{b}=0.79$ for pre-instrumental earthquakes. Their instrumental database of earthquakes included preinstrumental earthquakes.

Table 1

Earthquake size estimates for MAFS from the empirical equations by Wells and Copersmith (1994) and Stirling et al. (2002).

\begin{tabular}{|c|c|c|c|c|c|c|c|c|c|}
\hline SEG. & strike & $\begin{array}{l}\text { SRL } \\
(\mathrm{km})\end{array}$ & $\begin{array}{l}\text { age } \\
\text { (ka) }\end{array}$ & $\begin{array}{c}\mathrm{V} \\
(\mathrm{m})\end{array}$ & $\begin{array}{c}\text { Slip-Rate } \\
\mathrm{mm} / \mathrm{yr}\end{array}$ & $\begin{array}{l}\mathrm{Mw} \\
\text { (WC) }\end{array}$ & $\begin{array}{l}\mathrm{Mw} \\
(\mathrm{St0} 2)\end{array}$ & Reg. Type & $\begin{array}{l}\mathrm{PR} * \\
(\mathrm{ka})\end{array}$ \\
\hline$Q I$ & NE-SW & 20 & 700 & 100 & 0,143 & 6,6 & $\begin{array}{l}6,7 \\
6,9\end{array}$ & $\begin{array}{c}\text { Instr. } \\
\text { Pre-Instr. }\end{array}$ & 9--15 \\
\hline $\mathrm{Ch}$ & NE-SW & 30 & 300 & 60 & 0,200 & 6,8 & $\begin{array}{l}6,9 \\
7,1\end{array}$ & $\begin{array}{c}\text { Instr. } \\
\text { Pre-Instr. }\end{array}$ & $6.7--10$ \\
\hline TAO & NE-SW & 35 & 8000 & 200 & 2,778 & 6,9 & $\begin{array}{l}6,9 \\
7,1\end{array}$ & $\begin{array}{c}\text { Instr. } \\
\text { Pre-Instr. } \\
\text { ** }\end{array}$ & $\begin{array}{c}60--100 \\
? ?\end{array}$ \\
\hline$C M$ & ENE-WSW & 5,5 & 500 & 60 & 0,120 & 5,8 & $\begin{array}{l}6,2 \\
6,5\end{array}$ & $\begin{array}{c}\text { Instr. } \\
\text { Pre-Instr. }\end{array}$ & $4.5-8$ \\
\hline$L P$ & E-W & 12 & $\begin{array}{r}5300 \\
1,6\end{array}$ & $\begin{array}{l}300 \\
0,8\end{array}$ & $\begin{array}{l}0,057 \\
0,500\end{array}$ & 6,3 & $\begin{array}{l}6,5 \\
6,7\end{array}$ & $\begin{array}{c}\text { Instr. } \\
\text { Pre-Instr. } \\
* *\end{array}$ & $\begin{array}{r}10--20 \\
1.2--2.5\end{array}$ \\
\hline Mo & ENE-WSW & 6 & 5300 & 50 & 0,009 & 5,9 & $\begin{array}{l}6,2 \\
6,5 \\
6\end{array}$ & $\begin{array}{c}\text { Instr. } \\
\text { Pre-Instr. }\end{array}$ & $40--100$ \\
\hline$H u$ & $\mathrm{~N}-\mathrm{S}$ & 10 & 500 & 50 & 0,100 & 6,2 & $\begin{array}{l}6,6 \\
6,8 \\
6,4 \\
6,7\end{array}$ & $\begin{array}{c}\text { Instr. } \\
\text { Pre-Instr. } \\
\text { Instr. } \\
\text { Pre-Instr. }\end{array}$ & $4.5--10$ \\
\hline $\mathrm{Pa}$ & E-W & 15 & $\begin{array}{l}8 \\
3\end{array}$ & 20 & 2,500 & 6,4 & $\begin{array}{l}6,6 \\
6,8\end{array}$ & $\begin{array}{c}\text { Instr. } \\
\text { Pre-Instr. } \\
* *\end{array}$ & $? ?$ \\
\hline
\end{tabular}

Key: QI= Queréndaro-Indaparapeo, $C h=$ Charo, TAO= Tarímbaro and Alvaro Obregón,

$C M=$ Central Morelia, $L P=L a$ Paloma, Mo= Morelos, Ctz $=$ Cointzio, Hu= Huiramba and

$P a=$ Pátzcuaro.

$S E G=$ segment name, $S R L=$ surface ruture length, $V=$ total vertical displacement

WC $=$ Wells and Coppersmith (1994); St02 = Stirling et al. (2002)

Instr. = Instrumental database, Pre-instr. Preinstrumental database

** Short-term value

$\mathrm{PR}=$ Recurrence time period for the Mw interval at this slip-rate (*Slemons et al., 1982) 
The estimated earthquake magnitudes are shown in Table 1, indicating the type of the regression equation used (Wells and Coppersmith, 1994; Stirling et al., 2002). The fault slip-rate was estimated from paleoseismic studies, scarp morphology and landslides triggered by earthquakes.

We assume that the total surface length of these fault segments is equivalent to a single co-seismic surface rupture. This seems acceptable as MAFS exhibits a low incidence of instrumental earthquakes in comparison with the potential size obtained from empirical regressions of geological and paleoseismological data (Table 1). This suggests an "earthquake characteristic" model of seismic distribution at MAFS (Wesnousky, 1994).

\section{Queréndaro-Indaparapeo segment $(Q I)$}

QI segment begins at Los Azufres geothermal field (Figs. 1 and 2). It is oriented to ENE-WSW. Two dacitic domes were extruded and subsequently crossed by the fault. Towards Queréndaro, we find andesitic-basaltic lava flows dated at $700 \mathrm{ka}$ (Pradal and Robin, 1994), A >100 $\mathrm{m}$ scarp forms the southern boundary of the Queréndaro lacustrine depression. The segment shows a SRL value of $20 \mathrm{~km}$ (Fig. 2). The Mw value obtained from equation [1] ranges between 6.6 and 6.9 (Table 1) and the slip-rate is $0.14 \mathrm{~mm} / \mathrm{yr}$. By applying the Slemons' (1982) plot, the recurrence time period (PR) for this interval of earthquake magnitude is between 9 and $15 \mathrm{ka}$ (Fig. 5).

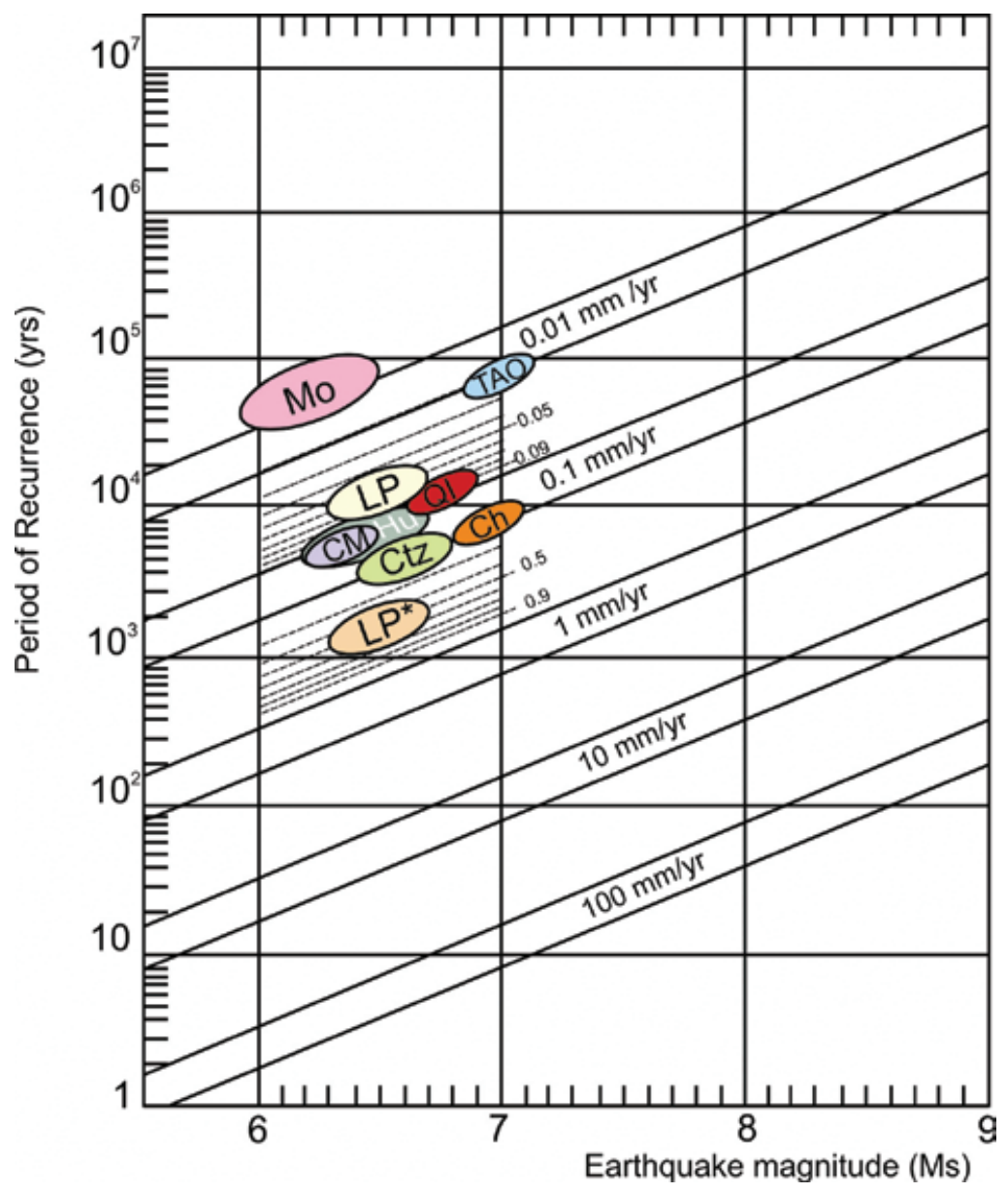

Fig. 5. Plot after Slemons (1982) estimating time interval recurrence (PR) versus earthquake magnitude and slip-rate (mm/yr). The ellipses indicate the fault segment of MAFS where the major axis is the difference between the maximum and minimum size of expected earthquakes in each segment, and the minor axis is one fifth of the slip-rate value (see text). Key: QI= Queréndaro-Indapapeo; Ch= Charo; $\mathrm{TAO}=$ TArímbaro and Alvaro Obregón; $\mathrm{CM}=$ Central Morelia; $\mathrm{LP}=\mathrm{La}$ Paloma; $\mathrm{Mo}=$ Morelos; $\mathrm{CTZ}=\mathrm{Cointzio} ; \mathrm{Hu}=\mathrm{Huiramba}$ and Pa= Pátzcuaro. LP* indicates the short-term slip-rate value for La Paloma. 
Small graben basins and "in echelon" normal faults are associated to the main fault segment in the vicinity of Queréndaro. These grabens configure a pull-apart basin indicating that QI presents secondary left-lateral fault movement.

\section{Charo segment (Ch)}

This segment is also within Los Azufres geothermal field and oriented NE-SW (Fig. 2). The youngest deposit affected by the movement of this segment is the rhyolitic dome of El Rosario (300 ka). Around Queréndaro this segment exhibits 10 cinder cones extruded through the Miocene rocks of Sierra Mil Cumbres. In the vicinity of Charo, this segment develops triangular facets that affected Miocene volcanic rocks of Sierra de Mil Cumbres and recent fluvio-lacustrine sediments around La Golera area. Ch presents a SRL of $30 \mathrm{~km}$ and from Ec (1), the $\mathrm{Mw}$ value varies between 6.8 and 7.1 (Table 1). The fault slip-rate is $0.2 \mathrm{~mm} / \mathrm{yr}$ and the interval period of recurrence (PR) is between 6.7 and $10 \mathrm{ka}$ (Fig. 5).

\section{Tarímbaro and Alvaro Obregón segment (TAO)}

Magnetometry and georadar techniques were used to study the geometry of this segment, mainly oriented to NE-SW and secondary E-W. TAO is $35 \mathrm{~km}$ long and exhibits a surface scarp greater than $100 \mathrm{~m}$ (Figs. 1 and 2). At its eastern part, TAO crossed lava flows aged 8 Ma (Israde, 1995) whereas at its western tip point, this segment displaces basaltic lava flows of El Quinceo - Las Tetillas volcano, lava flows containing corn cob moulds (Martínez and Hobson, 1907). The most recent fault movement generated surface displacements from a few up to tens of meters (Garduño-Monroy et al., 2001). Assuming that maize existed during the last $3.6 \mathrm{ka}$, the presence of maize in this fault segment means that was reactivated after $3.6 \mathrm{ka}$ (Watts and Bradbury, 1982).The western termination of this segment can be observed in the zone of Las Joyitas (NW of Morelia), where the fault acted as a vent for the extrusion of two cinder cones and subsequently crossed them. The garbage dump of the city of Morelia is located there.

Eq. (1) indicates that $\mathrm{Mw}$ ranged between 6.9 and 7.1 (Table 1). Hence, TAO segment presents a non-uniform fault slip-rate throughout time. The oldest materials Upper Miocene-Pliocene show a vertical displacement of $200 \mathrm{~m}$; thus the slip-rate is calculated $0.025 \mathrm{~mm} / \mathrm{yr}$ (Table 1). Best the youngest detected movement of $3.6 \mathrm{ka}$ generated a fault scarp of ca. $10 \mathrm{~m}$, suggesting a fault sliprate of $2.78 \mathrm{~mm} / \mathrm{yr}$, two orders of magnitude higher than the precedent value (Table 1). We suggest that the sliprate value depends on the time scale, i.e; the short-term is the Holocene slip-rate and the long-term is the Pliocene to Present-day slip-rate value. More data are needed. The PR interval for the long-term case is estimated at 60 to 100 ka (Fig. 5).

\section{Central Morelia segments (CM)}

CM is composed by two ENE-WSW normal fault subsegments, located within the City of Morelia (Fig. 2). They have downthrown blocks to the north and scarp heights of 20 to $60 \mathrm{~m}$. One of them is located in the northern part of the city (El Realito, Guadalupe and La Colina districts) and the other is the downtown area next to the bus station. Assuming total co-seismic rupture of both sub-segments SRL reaches ca. $5.5 \mathrm{~km}, \mathrm{Mw}$ ranges between 5.8 and 6.5. The fault slip-rate is $0.12 \mathrm{~mm} / \mathrm{yr}$ and the PR from 4.5 to 8 ka (Table 1).

Surface subsidence occurs along this fault at a rate of 4 to $6 \mathrm{~cm} / \mathrm{yr}$ (Garduño et al., 1998; 1999a), two orders of magnitude faster than the seismic slip-rate (see also Suter et al., 2001). It could cause severe damage to buildings. This process may be a result of over exploitation of groundwater.

\section{La Paloma segment (LP)}

LP segment is oriented to E-W and separates the valley of Guanyangareo (Plio-Quaternary volcanism) and lacustrine sedimentation, from the area of Mesa of La Loma de Santa María and the Sierra de Mil Cumbres (Fig. 2). LP affects Miocene ignimbrites and Pliocene fluviolacustrine sediments. At its eastern part, it generates a surface throw of about $200 \mathrm{~m}$ and a vertical displacement of the Morelia ignimbrite by $300 \mathrm{~m}$. West of the city, the surface scarp progressively decreases and nearly disappears. Many landslides are visible alongside the fault scarp, in the City of Morelia these slides are slowly being covered by urbanization (e.g. in La Paloma - Ocolusen sector) (Garduño et al., 1998). The Jaripeo fault forms the eastern prolongation of La Paloma with a slightly different orientation (ENE-WSW).

The SRL of LP is $12 \mathrm{~km}$ length, and Mw varies between 6.3 and 6.7 (Table 1.). This segment also presents different fault slip-rates values according to the time period, 0.057 $\mathrm{mm} / \mathrm{yr}$ for long-term and $0.5 \mathrm{~mm} / \mathrm{yr}$ for short-term (Israde, 1995) (Table 1). The short-term value is one order larger than the short-term value. Therefore, the PR for long-term varies between 10 and $20 \mathrm{ka}$ (Pliocene to Present days), whilst for the short-term (Holocene) this interval is 1.2 to $2.5 \mathrm{ka}$ for the same earthquake size range $(6.3<\mathrm{Mw}<6.7)$ (Fig. 5).

We studied two detailed cross-sections on the talus of La Paloma segment, southern part of Morelia, where 
excavations for engineering structures were carried out. The first cross-section was performed at $2000 \mathrm{~m}$ a.s.1. showed the following stratigraphy (Fig. 6A):

1. (B1) A basal breccia composed of ignimbrite blocks and lithified debris flow deposits.

2. (P1) A dark paleosol containing pottery shards of the Pirinda culture over the basal breccia or debris flow deposit. This paleosoil was dated by ${ }^{14} \mathrm{C}$ method at $\sim 1.6$ ka. A normal fault with almost $90^{\circ}$ striae pitch displaces the paleosol producing a vertical separation of $\sim 80 \mathrm{~cm}$, which translates into a slip rate of $0.5 \mathrm{~mm}$ per year.
3. (C1) Overlying P1 we find unstable slope material or present-day organic soil. The second cross-section was southeast of Morelia, in the vicinity of Ocolusen, in an excavation for a water reservoir. The eastern wall of the trench exposed (Fig. 6B):

1. (B1) A basal layer of of andesitic blocks of lava and pyroclasts. A fault (white line, 1) extends to the overlying soil and is filled with secondary material. Faults form a small graben in the basal layer filled with colluvium I.

2. (C1) Colluvium I, is a clay matrix with andesitic fragments. It is cut by fault planes. The throw of these

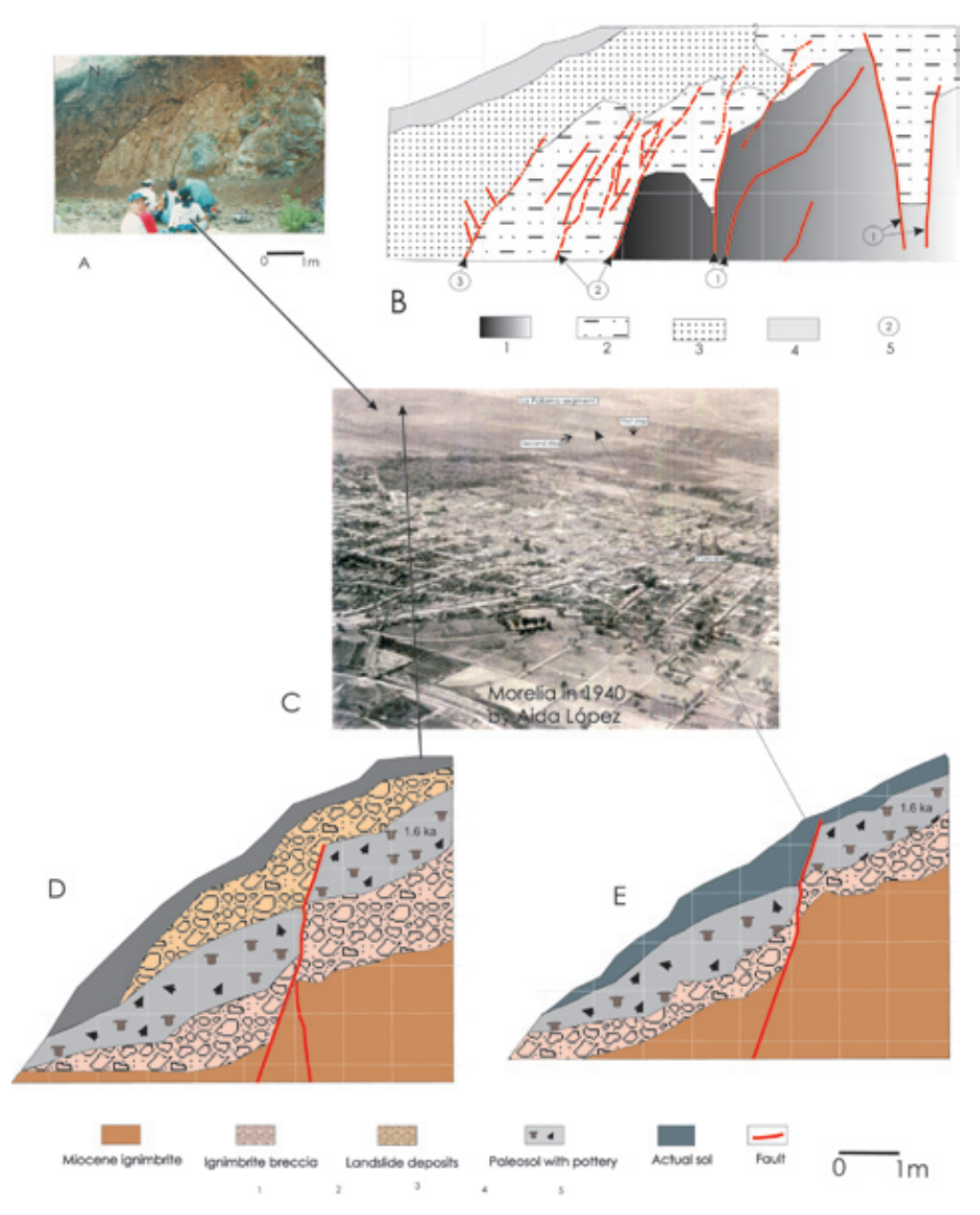

Fig. 6. Cross-sections of stratigraphic sites along La Paloma Fault segment. A. A and B (log) normal fault that cuts colluvial deposit with pottery shards (1200 AC, Classic period, Pirindas culture). Three faulting events are observed. The first event is a fault in Miocene andesites that produced a small basin (graben) in the same rocks and colluvium I. The second event is a normal fault that cuts only the colluvium I, and apparently, this fault were eroded to the colluvium II (that also has pottery remains of the Classic period). The last faulting event is associated with the colluvium II deposit. B, Rocks and deposit numbers are: 1. Miocene Andesites, 2. Colluvium I, 3. Colluvium II, 4. Present soil, and 5. Faulting event. C). Photographs from Morelia, We can see de principal steps of La Paloma Fault and localization of the three trenches. D). and E). Tranches from the Post Classic earthquake at la Paloma Fault. 
planes is over $50 \mathrm{~cm}$. They form steps toward the north and are oriented E-W. Colluvium I fills the graben and the steps formed by faults (1) and are cut by faults (2).

3. (C2) Colluvium II deposits of clay matrix with abundant andesitic fragments.

Synthetic and antithetic faults to fault 3 cut the base of this deposit. Pottery shards.

4. (S1) Undisturbed recent organic soil.

\section{Morelos segment (Mo)}

Mo segment is $6 \mathrm{~km}$ long south of Morelia City (Figs. 1 and 2). The main orientation is to ENE-WSW affecting Upper Miocene to Pliocene deposits (Morelia ignimbrite). The accumulated vertical fault displacement is ca. $50 \mathrm{~m}$ Mw ranges between 5.9 and 6.5 and this segment exhibits the lowest slip-rate in the studied area $(0.009 \mathrm{~mm} / \mathrm{yr})$ (Table 1). By applying the Slemons' (1982) curve, the PR varies between 40 and $100 \mathrm{ka}$. Mo may be considered as a bifurcation of the Cointzio segment $(\mathrm{Ctz})$.

\section{Cointzio segment (Ctz)}

Ctz segment cuts Miocene rocks, Morelia ignimbrite and, towards the west, displaces the eastern flank of the Cerro El Aguila shield volcano (Fig. 2). It is a normal fault oriented towards NE-SW, with a downthrown block to the north and with a scarp of 100 meters height. It forms the northern border of the Cointzio dam at Cerro El Aguila, it displaces lavas of $500 \mathrm{ka}$. Considering the scarp height, the estimated slip- rate is $0.2 \mathrm{~mm} / \mathrm{yr}$. Ctz is a $15 \mathrm{~km}$ long (Figs. 2 and 3) and may generate earthquakes with $\mathrm{Mw}$ between 6.4 and 6.8 and with a period of recurrence $30<$ PR $<60$ ka.

\section{Huiramba segment $(\mathrm{Hu})$}

This fault segment is discontinuous and extends from the southern part of Huiramba to Cerro El Aguila (Fig. 2). The main orientation of $\mathrm{Hu}$ is to N-S and with a SRL value of $10 \mathrm{~km}$. Towards the SW of the Cerro El Aguila volcano, the orientation of Hu changes NNE-SSW. Near of the town of Hiuramba, this segment shows normal faulting with hanging walls to the $\mathrm{W}$ and surface throw of about $50 \mathrm{~m}$. A small graben with the same orientation N-S is developed on the southern side of the Cerro El Aguila volcano. Hu affects andesitic-dacitic domes with an age lesser than 500 ka (Pasquaré et al., 1991; Garduño et al., 1999b). The earthquake magnitude interval is $(6.2-6.7)$ with a fault slip-rate of $0.1 \mathrm{~mm} / \mathrm{yr}$. The time period of recurrence varies between 4.5 and $10 \mathrm{ka}$.

\section{Pátzcuaro segment $(\mathrm{Pa})$}

$\mathrm{Pa}$ segment extends from Erongaricuaro to the City of Pátzcuaro (Fig. 2), and is oriented to E-W. This segment develops the graben of Jaracuaro-Pátzcuaro, which is related to the almost $40 \mathrm{~m}$ uplift of the island of Jaracuaro. The volcano La Taza (8 Ka) $\left(19^{\circ} 31^{\prime} 35^{\prime \prime} \mathrm{N}\right.$; $101^{\circ} 43^{\prime} 29^{\prime \prime} \mathrm{W}$ ) and the avalanche deposits and collapse of volcano El Estribo, are related to the Pa segment. These avalanche deposits and collapse were generated by $M>6$ earthquakes (Israde-Alcantara et al., 2005).

The SRL value suggests earthquakes ranging between 6.4 and 6.8 from the empirical regressions of Wells and Coppersmith (1994) and Stirling et al. (2002) (Table 1). The tectonic uplift of Jaracuaro Island and the age of the last paleoseismic event, suggest a fault slip-rate greater than $2.5 \mathrm{~mm} / \mathrm{yr}$. This value exceeds slip-rates for the precedent segments of MAFS (see Table 1), by one order of magnitude, but is similar to the short-term slip-rate for the TAO segment (Fig.5). We interpret this value as the short-term slip-rate for the Pa segment (Holocene).

The main result of the seismotectonic analysis is a estimated M7.1 the potential maximum expected earthquake, with PR values ranging between 60 and 100 ka (TAO segment)(Table 1). The minimum PR interval is (4.5-8) $\mathrm{ka}$ for earthquake sizes of (5.8-6.5) in the CM segment. The $\mathrm{Ch}$ segment presents the same potential maximum size M7.1, but PR is between 6.7 and $10 \mathrm{Ka}$. All segments are near Morelia City, thus the seismicity is relevant for future hazard studies.

\section{Discussion}

\section{Age of the Morelia-Acambay Fautling}

The age of the TMVB has been controversial. Recent dates have established that volcanism in this arc began $\sim 12$ Ma ago (Garduño-Monroy and Gutierrez, 1999, Pasquare, et al, 1991, Ferrari et. al, 1994). In the study area, the oldest lacustrine sequence has Miocene-Pliocene age. In the Charo region the oldest lacustrine deposits were dated at $7 \mathrm{Ma}$ (Israde, 1995). At Los Azufres, Pradal and Robin (1994) dated monogenetic volcanism of Querendaro at 700 $\mathrm{ka}$ and the lavas were cut by the Morelia-Acambay fault. Further north, in the Araro region, proximal lacustrine deposits with Pirinda-Purhepecha pottery shards were raised $20 \mathrm{~m}$ by the E-W faults. In the Morelia region, the MAFS structures displace Upper Miocene (12 Ma) volcanic sequences while further north, in the Tarimbaro region, E-W faults cut the lavas of the Holocene Quinceo volcano, that contain maize cob casts (Fig. 8). Fallout deposits of the Quinceo-Las Tetillas volcanoes containing pottery shards were also displaced by E-W faults. 
Paleontological studies performed between Acambay and Cuitzeo suggest the following dates (Fig. 7):

1. In Tierras Blancas and San Bartola Lanzados, Acambay, Mercer et al. (2002) reported interbedded lacustrine sequences with fallout layers of ash and pumice dated at 1.2 Ma (Late Pliocene-Early Pleistocene). These lacustrine layers contain Equus simplicidens, c.f. Rhynchotherium ?, Camelops sp., Mammuthus sp., Bison sp. and Antilocarpa sp (Fig.7). This fauna confirms the of Pliocene-Pleistocene age of this lacustrine basin and an important tectonic activity synsedimentary.

2. The Pastores fault south of Tierras Blancas and San Bartola Lanzados basin displaces lavas dated by Suter $e t$ al. (1995) at 0.4 Ma (Pleistocene).

3. In a small E-W basin in Chincua, a lacustrine column revealed molars of Equus sp. and Cuvieronis sp., which assigns a Miocene-Pliocene age to the deposits (Fig. 7). The lacustrine sequence is covered by a gray ignimbrite deposit dated 4 Ma (Pradal and Robin, 1985), which agrees with a Miocene-Pliocene age the basin.

4. In Zaragoza, Michoacan, remains of Mammuthus columbi (Falconer) 1857 was found in a small basin bounded by E-W faults, dated Middle to Late Pleistocene.

5. Several authors have made stratigraphic and paleontological studies in a lacustrine sequence in Charo that is tilted and cut by E-W and NNW-SSE faults (Israde-Alcantara 1995, 1999). They found recorded a rich vertebrate fauna of Proboscidea, Artiodactyla, Perissodactyla, Lagomorpha, Rodentia and Birds from Early Pliocene to Pleistocene, as corroborated by a date of 3.6 Ma a cinder cone (Arellano and Azcón., 1949; Repenning, 1962; Carranza, 1976; Miller and Carranza, 1984; Israde, 1999) (Fig.7). Israde (1995) reported a date from the lacustrine sequence base of $7 \mathrm{Ma}$ (Upper Miocene).

\begin{tabular}{|c|c|c|c|}
\hline & $\begin{array}{l}\text { Hemphilliane } \\
\text { (Miocene-Pliocene) }\end{array}$ & Blancane(Pliocene) & Pleistocene \\
\hline Charo & After 8Ma. & & \\
\hline $\begin{array}{l}\text { Nannippus cf. } \\
\text { Moctezuma (Leidy) }\end{array}$ & $\mathbf{H}$ & B & \\
\hline Neohipparion & $\mathrm{H}$ & & \\
\hline Dinohippus & $\mathrm{H}$ & & \\
\hline Astrohippus & $\mathrm{H}$ & & \\
\hline $\begin{array}{l}\text { Equus (Dolichohippus) } \\
\text { simplicidens, }\end{array}$ & H? & & \\
\hline Gomphotherium, & $\mathrm{H}$ & & \\
\hline Neotoma & $\mathrm{H}$ & B & $\mathrm{P}$ \\
\hline $\begin{array}{l}\text { Paenemormota } \\
\text { barbouri }\end{array}$ & $\mathrm{H}$ & B & \\
\hline Mammuthus columbi & & & $\mathrm{P}$ \\
\hline Cuvieronius & & B & $\mathrm{P}$ \\
\hline Bison latifrons & & & $\mathrm{P}$ \\
\hline Sylvilagus & & $\mathrm{B}$ & $\mathrm{P}$ \\
\hline Chincua & Before $4 \mathrm{Ma}$ & & \\
\hline Equus? & $\mathrm{H} ?$ & B & $\mathrm{P}$ \\
\hline Acambay & After $4 \mathrm{Ma}$ & & \\
\hline Equus simplicidens & $\mathrm{H} ?$ & B & $\mathrm{P}$ \\
\hline cf. Rhynchotherium?, & & B & \\
\hline Camelops, & & B & $\mathrm{P}$ \\
\hline Mammuthus sp., & & & $\mathrm{P}$ \\
\hline Bison sp. & & & $\mathrm{P}$ \\
\hline Antilocapra sp. & & & $\mathrm{P}$ \\
\hline $\begin{array}{l}\text { Tzintzuntzan- } \\
\text { Patzcuaro }\end{array}$ & After $2 \mathrm{Ma}$ & & \\
\hline Canis & $\mathrm{H}$ & & $\mathrm{P}$ \\
\hline Equus. Sp & & B & $\mathrm{P}$ \\
\hline Thomomys umbrinus & & & $P$ \\
\hline Pappogeomys sp. & & & $\mathrm{P}$ \\
\hline Sylvilagus floridanus & & B & $\mathrm{P}$ \\
\hline Odocoileus virginianus & & & $\mathrm{P}$ \\
\hline
\end{tabular}

Fig. 7. Paleontological age of lacustrine basins Morelia-Acambay, after. Arroyo-Cabrales, J., et al. (2002) and INAH 
The evidence suggests that MAFS structures originated in the Upper Miocene. By $7 \mathrm{Ma}$, the lacustrine basins were depressions that were accumulating sediments, their origin must date back to 8-10 Ma ago as does inception of the E-W Morelia-Acambay faults.

Activity of some segments of MAFS is demonstrated at La Paloma where historical paleosols dated at $1.6 \mathrm{ka}$ are displaced. Fallout contains pottery shards and the Araro lacustrine sediments contain prehispanic ceramics.

The October 17, 2007 seismic swarm (Fig. 9)

Four small earthquakes occurred on October 17, 2007, around the City of Morelia. Three of these events were located by the National Seismological Service. They had magnitudes varying from 3.5 to 3.8 , with depths between 1-6 km. Such shallow events were not related to subduction of the Cocos Plate, they originated along E-W segments of MAFS. The epicenters of were located along the Central Camionera fault. The length of this fault $(8$ $\mathrm{km}$ ), suggests that it originate an earthquake of magnitude $>3$ and accelerations of 1-2 gales. Such an event can be felt by the population, as in the case of the October 2007 events. The focal mechanism of the earthquakes agrees with the geometry of the Central Camionera fault and possible segments to the west. (Fig. 9)

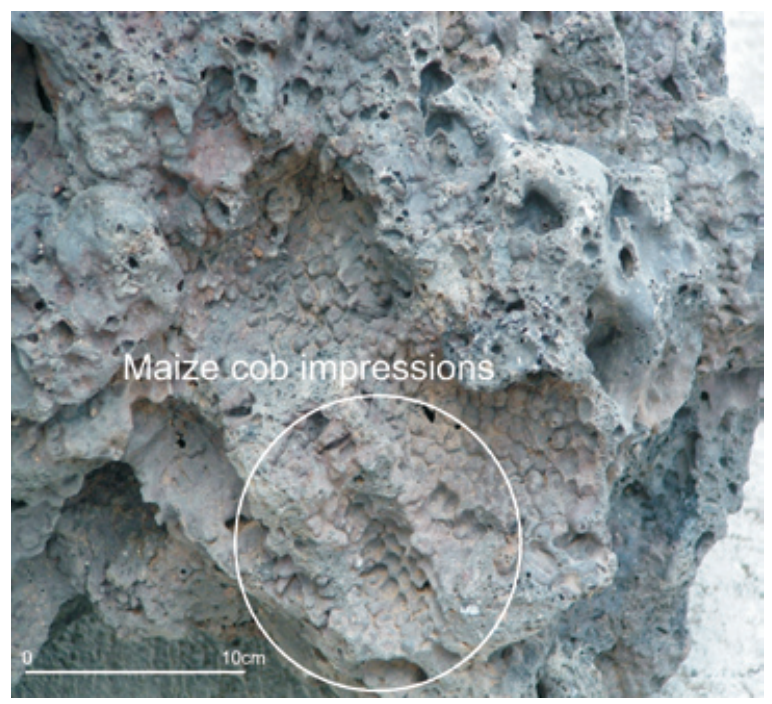

Fig. 8. Maize cob impressions in lavas from the Quinceo-Las Tetillas volcano.

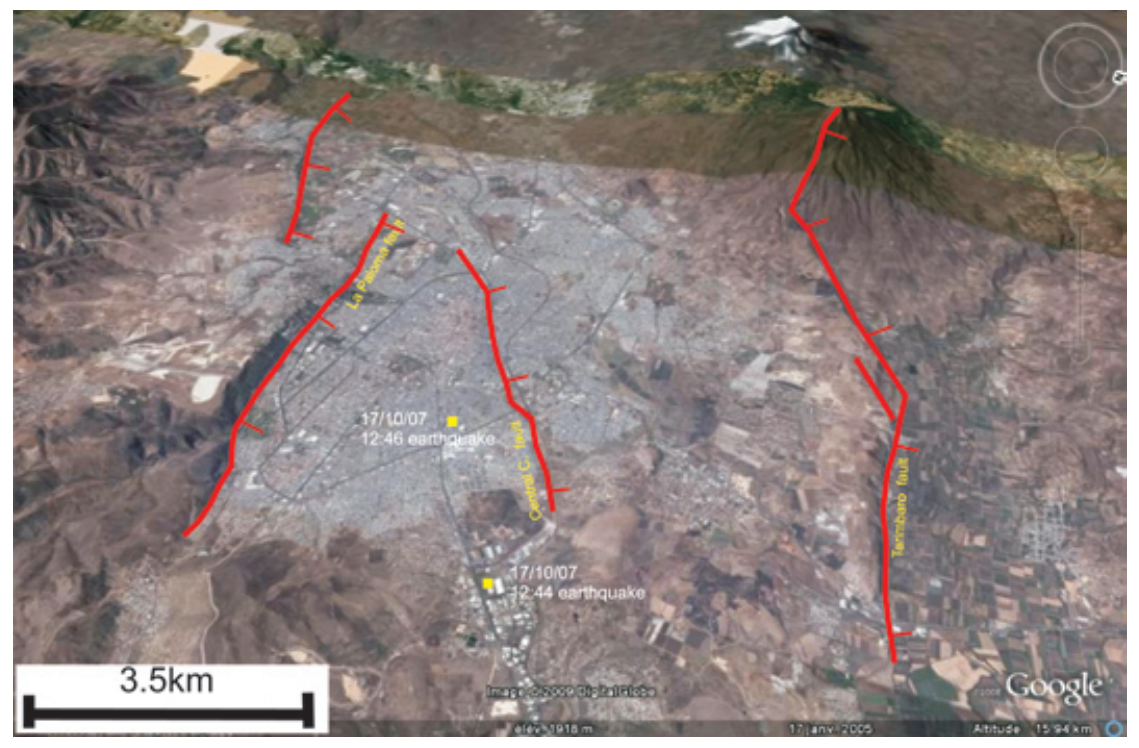

Fig. 9. Location of the October 172007 earthquakes in the City of Morelia. 
This earthquake activity corroborates that E-W segments of MAFS are subjected to a regional tensional field of the TMVB, and that they may be reactivated in the future. At present, only a small segment of MAFS has been activated; if the regional tensional field activates a larger segment (i.e. La Paloma fault) a stronger earthquake could occur with damage to the urban area of Morelia, as in the 1858 earthquake.

\section{Fault inception and evolution of lacustrine depressions}

The NNW-SSE faults have often been considered to be structures inherited from the north Mexican Basin and Range province. However, our study suggests that these faults may have been reactivated during the formation of the lacustrine depressions of the TMVB, since the orientation of these basins corresponds to a $\sigma_{3}$ extension with a NW-SE orientation that is still active in the central part of the TMVB, Therefore the inherited NW-SE structures have a right-lateral component. This may be observed in the Tzitzio-Valle de Santiago structure, which must be a northern component of the Taxco-Queretaro Fault System that strongly controls the distribution of volcanism, causing displacement towards the SE (Garduño-Monroy and Gutierrez, 1992).

The scarps of MAFS in the study region have heights ranging between 20 and $200 \mathrm{~m}$. They are often larger at the eastern end of the fault. For example, the eastern tips of La Paloma and Tarímbaro segments terminate abruptly with scarps higher than $200 \mathrm{~m}$. Toward the west the scarp height decays gradually to $\sim 20 \mathrm{~m}$. These faults must be linked at depth to the eastern segments a cross relay ramps. The Tarimabro fault would be linked to the Alvaro Obregon fault and the La Paloma fault to the Jaripeo fault (Fig. 2). If so, the Morelia-Acambay fault system may be coalescence stage (see also Suter et al., 2001), with individual faults linked at depth. Collapse scars are found in Pátzcuaro and throughout the region (e.g. at Pátzcuaro lake islands or La Paloma fault). Therefore, it appears that the Patzcuaro and La Paloma faults are seismically active, with Holocene and historical earthquakes as recorded. The Araro segment is also active as suggested by displacements in historical lacustrine units plus recent seismicity (Valdés-González and Pérez-Esquivias, 2007).

Earthquakes in the central TMVB are either subduction-related (deep interplate or intermediate-depth normal faults), shallow MAFS-related earthquakes. Both types of earthquakes might respond to regional structure of MAFS. For the western MAFS segments, the historic seismicity (two major earthquakes in 1845 and 1858) felt in Morelia and Pátzcuaro, could not be related to E-W striking faults. Instead, the shape of the 1845 and 1858 earthquakes isoseismals reveals that even in subduction- related earthquakes, the distribution of lacustrine sediments related to E-W faults controls the intensity of damage. The response of the terrain depends of the underlying material. In the studied area, there are two different types of substrate:

(1) In the Pátzcuaro region, lava flows overlie lacustrine clays oversaturated with. The 1858 earthquake caused a water level rise in Pátzcuaro Lake, possibly in response to pressure exerted on oversaturated clays. A tsunami in the lake caused the collapse of over 120 adobe houses. El Estribo, El Metate and Janitzio volcanoes have suffered major collapses during seismic events over the last $30 \mathrm{ka}$.

(2) In Morelia, ancient lacustrine plains are vulnerable to earthquakes. A seismic microzonification study revealed that some quarters (Prados Verdes, Policía, and Tránsito) responded unfavorably to earthquakes, A larger earthquake may cause sever losses (Lermo-Samaniego et al., 1999).

\section{Conclusions}

Prior to this study, E-W oriented faults of the MoreliaAcambay system where thought to have been originated around 5-6 Ma (Israde, 1995). Lie fiend that this fault dates from $\sim 8 \mathrm{Ma}$ and that some segments were reactivated during the Pleistocene including the Queréndaro-Indaparapeo segment ( $<700 \mathrm{ka})$, the Cointzio and Huiramba segments $(<500 \mathrm{ka})$, the Pátzcuaro segment ( $<30 \mathrm{ka}$ and during historic times), the Tarímbaro segment ( $<3.6 \mathrm{ka})$, La Paloma segment (twice after $1.6 \mathrm{ka}$ with displacements of ca. $80 \mathrm{~cm}$ ), and the Charo segment (during the Holocene). These results suggest that the region is prone to shallow intraplate seismicity. Known historic earthquakes have occurred at the eastern tip of the MAFS affecting areas from Los Azufres geothermal field to the Acambay region (Suter et al., 1996). Population in the western edge of MAFS has increased over the past decades to 1.5 million including Morelia, Pátzcuaro, Zinapécuaro and smaller towns. Renewed seismic activity in the region poses a serious threat to this population. Paleoseismicity studies in the region of Morelia and Pátzcuaro may improve the estimates of recurrence of earthquakes and displacement along these faults, in order to assess the hazard.

\section{Acknowledgements}

This work was supported by the CONACyT grant 37334-T and by the Coordinación de la Investigación Científica-UMSNH (1.17). Thanks to Sergio Zárate for translating the manuscript. Thank so much at the editor Dr. Cinna Lomnitz for your help and excellent comments. 


\section{Bibliography}

Arroyo-Cabrales, J., O. J. Polaco, E. Johnson and A. F. Guzmán, 2002, The Distribution of the genus Mammuthus in México: Deinsea 9, Annual of the natural History Museum Rotterdam, 27 - 40.

Astiz-Delgado, L. M., 1980. Sismicidad en Acambay, Estado de México- el temblor del 22 de febrero de 1979: México, D.F., UNAM, Facultad de Ingeniería, unpublished thesis, $130 \mathrm{p}$.

Bradbury, P., 2000. Limnology history of lago de Pátzcuaro, Michoacan, México for the past 48,000 years: impacts of clima and man. Palaeogeography, Palaeoclimatology, Palaeoecology 163, 69-95.

Connor, C. B., 1990. Cinder cone clustering in the TransMexican Volcanic Belt: Implications for Structural and Petrologic Models. J. Geophys. Res. 95, B12, 19, 395-19,405.

CRM, 1996. Carta magnética de campo total reducido al polo. Sheet Querétaro, F14-10.

CRM, 1998. Carta magnética de campo total reducido al polo. Sheet Morelia, E14-1.

De Cserna, Z., M. De La Fuente-Duch, M. Palacios -Nieto, L. Triay, L. M. Mitre-Salazar and R. Mota-Palomino, 1988. Estructura Geológica, Gravimetría, Sismicidad y Relaciones Neotectónicas Regionales de La Cuenca de México. Boletín del Instituto de Geología, UNAM, México, 104, p. 1-71.

Demant, A., 1978. Caracteristicas del Eje Neovolcánico Transmexicano y sus problemas de interpretación. UNAM, Inst. Geol. Revista, 2, 2, 172-187.

Demant, A.,1981. L'Axe Néo-volcanique Transmexicainétude volcanologique et pétrographique; signification géodinamique: Marselle, Université du Droit, d'Economie et des Sciences d'Aix-Marseille. PhD. Thesis. 259p.

Bath and Duda, 1964. «Earthquake volume, fault plane area,seismic energy, strain, deformation and related quantitatives. Ann. Geofis. Rome, 17. pp 353-368

Ferrari, L., V. H. Garduño, G. Pasquaré and A. Tibaldi, 1994. Volcanic and tectonic evolution of the central Mexico: Oligocene to Present. Geofísica Internacional, 33, 1, p 91-105.

Flores, T., 1920. Estudio geológico minero del distrito El Oro-Tlalpujahua: UNAM, Instituto de Geología, Bol.37, 87 p.
Figueroa, J., 1974. Isosistas de macrosismos mexicanos, Ingeniería, México, 33, 1, pp45-67.

Instituto Nacional de Antropología e Historia (INAH). Base de datos electrónica (inédita), México

García-Palomo, A., J. L. Macías and V. H. Garduño, 2000. Miocene to recent structural evolution of the Nevado de Toluca volcano region, Central Mexico. Tectonophysics, 318, Nos. 1-4.

Garduño, M.V.H. and N.A. Gutierrez, 1992. Magmatismo, hiatus y tectónismo de la Sierra Madre Occidental y del Cinturón Volcánico Mexicano. Geofísica Internacional 31, p.417-429.

Garduño, M. V. H. and T. R. Escamilla, 1996. Revisión Histórica de la Sismicidad en Michoacán, México. Ciencia Nicolaita 11, p. 57-81.

Garduño, V. H., I. Israde, L. Francalanci, O. Carranza, S. Chiesa, P. Corona and E. Arreygue, 1997. Sedimentology, Volcanism and Tectonics of the southern margin of the lacustrine basins of Maravatio and Cuitzeo, Mich., Mexico. IAVCEI, General Assambly, 1997 19-24, Puerto Vallarta Mexico. 15 p.

Garduño, V. H., R. E. Arreygue, S. Chiesa, I. Israde, G. M. Rodríguez and G. M. Ayala, 1998. Las fallas geológicas y sísmicas de la Ciudad de Morelia y su influencia en la planificación del territorio. Ingeniería Civil, 1, 5, p. 3-12.

Garduño-Monroy, V. H., G. M. Rodríguez-Torres, I. Israde-Alcantara, E. Arreygue, P. Canuti and S. Chiesa, 1999a. "Efectos del clima (El Niño) en los fenómenos de Fluencia de las fallas geológicas de la Ciudad de Morelia". Geos, 19, 2, p.84-93.

Garduño-Monroy, V. H., P. Corona-Chávez, I. IsradeAlcantara, L. Mennella, E. Arreygue, B. Bigioggero and S. Chiesa, 1999b. Carta geológica de Michoacán. 1:250,000. UMSNH. $111 \mathrm{p}$.

Garduño-Monroy, V. H., E. Arreygue-Rocha, I. IsradeAlcantara and G. Rodríguez-Torres, 2001. Efectos de las Fallas asociadas a sobreexplotación de acuíferos y la presencia de fallas potencialmente sísmicas en Morelia, Michoacán, México. Revista Mexicana de Ciencias Geológicas, 18, 1, p.37-54.

Gasse, F. 1986, East African Diatoms, Taxonomy, Ecologycal Distribution. Biblioteca diatomologica. Berlin Stuckard. 203 p.

Henry, C. D. and J. J. Aranda, 1992. The real southern 
Basin and Range: Mid- to late Cenozoic extension in Mexico. Geology, 20, p. 701-704.

Israde, I., 1995. Bacini lacustri del settore centrale dell'Arco Vulcanico Messsicano: Stratigrafia ed evoluzione sedimentaria basata sulle diatomee. $\mathrm{PhD}$ Thesis, Universita degli Studi di Milano, Italia, 254 p.

Israde-Alcántara, I. and V. H. Garduño-Monroy, 1999. Lacustrine record in a volcanic intra-arc setting. The evolution of the Late Neogene Cuitzeo basin systeme (Central wester Michoacan, Mexico). Palaecogeography, Palaoclimatology, Palaecology 15, 1-3, 209-227.

Israde, I., V. H. Garduño and M. Ferrari, 1992. El origen transtensivo de la depresión del lago de Cuitzeo, Mexico. Actas de las Sesiones Científicas, Congreso Latioaméricano de Geología, Salamanca, España. 4, p.127-131.

Johnson, C. A., 1986. A study of neotectonics in central Mexico from a LANDSAT Thematic Mapper imagery: Coral Gables, Florida, Rosentiel School of Marine and Atmospheric Science, University of Miami, Master's thesis, $112 \mathrm{p}$.

Johnson, C. A. and C. G. A. Harrison, 1989. Tectonics and Volcanism in Central Mexico: A Landsat Thematic Mapper Perspective. Remote Sens. Environ., 28, p. 273-286.

Johnson, C. A. and C. G. A. Harrison, 1990. Neotectonics in central Mexico. Physics of the Earth and Planetary Interiors, 64, p. 187-210.

Keefer, D. K., 1994. The importance of earthquakeinduced landslides to long-term slope erosion and slope-failure hazards in sesimically active regions. Geomorphology, 10, p. 265-284.

Kilham, P. and S. Kilham, 1975. Melosira granulata (Her.) Ralfs Morphology and ecology of a cosmopolitan freshwater diatom. Verh. Int. Verein.Limnol, 19: 27162721.

Langridge, R. M., R. J. Weldon, J. C. Moya, G. Suárez, 2000. Paleoseismology of the 1912 Acambay earthquake and the Acambay-Tixmadejé fault, TransMexican Volcanic Belt. J. Geophys. Res., 105, B2, p. 3019-3037.

Lermo-Samaniego, J., V. H. Garduño-Monroy, E. Arreygue-Rocha,I.Israde-Alcantara and G. RodríguezTorres, 1999. Microzonificacón sismica preliminar de la ciudad de Morelia, Michoacán, México. Memorias del XII Cong. Nac. De Ing. Sis. P. 137-145.

Martínez, S. M. and B. Hobson, B., 1907. Restos de plantas en basaltos. Boletín de la Sociedad Michoacana de Geología y Estadística., Tomo. III, 15, p 238-240.

Martínez-Reyes, A. and A. F. Nieto-Samaniego, 1990. Efectos Geológicos de la Tectónica Reciente en la Parte Central de México. Rev. del Inst. Geol., 1, pp.3350.

Mennella, L., V. H. Garduño and O. Bonassi, 2000. Faultslip analysis in the basal units of the Mexican Volcanic Belt on the eastern flank of the Tzitzio Anticline, Michoacan Mexico. GSA Spec. Pap., 334, p. 237246.

Pasquaré, G., L. Ferrari, V. H. Garduño, A. Tibaldi, A. and L. Vezzoli, 1991. Geology of the central sector of the Mexican Volcanic Belt, States of Guanajuato and Michoacán. Geological Society of America Map and Chart series, MCH072, 22 p.

Pradal, E. and Robin, 1994. Long-lived magmatic phases at Los Azufres volcanic center, Mexico. Jour. Vol. and Geoth. Res. 63, p. 201-215.

Quintero-Legorreta, O., R. Mota-Palomino and M. Suter, 1988. Esfuerzos y deformación contemporáneos en la parte central de la Faja Volcánica Transmexicana; Y. Geometría, Distribución y Sismicidad de las fallas activas. Geos, Num, extraordinario, epoca II, Resumenes de la UGM.

Ramírez, S. and V. Reyes, 1873. Informe sobre los temblores y volcanes de Agua Fría y Jaripeo, Bol. Soc. Geogr. Mex., época 3, 1, pp.67-88.

Ramírez-Herrera, M. T., 1996.Morphological Evidence for Neotectonic Activity and seismic Hazard in the Acambay Graben, Mexican Volcanic Belt. Geomorphic Hazards, Ed. Olav Slaymaker, John Wiley \& Sons, 2941.

Sánchez-Garcillazo, V., 2000. Estudio de la Macrosismicidad del Estado de Michoacán. Facultad de Ingenieria Civil. These.133p.

Singh, S. K., M. Ordaz and L. Pérez-Rocha, 1996. The great Mexican earthquake of 19 june 1858: expected ground motion and damage in Mexico City from a similar future event. Bull.Seism. Soc. of America. 86, 6, pp.1655-1666.

Slemons, D. B. 1982. Determination of design earthquake magnitudes for microzonation. In: Proceedings of 
the 3rd International Earthquake Microzonation Conference. Seatle, Washington. 119-130.

Stirling, M., D. Rhoades and K. R. Berryman, 2002. Comparison of earthquake scaling relations derived from data of the Instrumental and Preinstrumental Era. Bull. Seismol. Soc. Amer. 92, 2, 812-830.

Suter, M., G. Aguirre, C. Siebe, O. Quintero and J. C. Komorowski, 1991. Volcanism and active faulting in the central part of the trans-Mexican volcanic belt, Mexico. In Walawender M.J. and Hanan B.B., eds. Geological excursions i souther California and Mexico; Geological

Suter, M., O. Quintero and C. A. Johnson, 1992. Active faults and state of stress in the central part of the trans-Mexican volcanic belt. 1. The Venta del Bravo Fault: Journal of Geophysical Research, 97, p. 1198311994.

Suter, M., M. Carillo-Martínez, M. López-Martínez and E. Farrar, 1995a. The Aljibes half- graben: Active extensión at the boundary between the trans-Mexican volcanic belt and the Basin and Range Province, Mexico. Tectonics, 14, 5, 1245-1262.

Suter, M., O. Quintero-Legorreta, M. López-Martínez, G. Aguirre-Díaz and E. Farrar, 1995b. The Acambay graben: Active intraarc extensión in the trans-Mexican volcanic belt, Mexico. Tectonics, 14, 5, 1245-1262.

Suter,M.,M.Carrillo-Martínez and O. Quintero-Legorreta, 1996. Macroseismic Study of Shallow Earthquakes in the Central and Eastern Parts of the Trans-Mexican Volcanic Belt, Mexico. Bulletin, Seismological Society America., 86, 6, p. 1952-1963.

Suter, M., M. López-Martínez, O. Quintero-Legorreta and M. Carrillo-Martínez, 2001. Quaternary intra-arc extension in the central Trans-Mexican volcanic belt. GSA Bull. 113, 6, p. 693-703.

Szynkaruk, E., V. H. Garduño-Monroy and G. Bocco, 2004. Active fault systems and tectono-topographic configuration of the central Trans-Mexican Volcanic Belt. Geomorphology, 61, p. 111-126.

Urquiza, M., 1872. Informe del ingeniero encargado de reconocer la sierra de Ucareo para everiguar las posibilidades de una erupción volcánica. Bol.Soc. Geogr. Mex. época 2, 4, pp,586-588.
Urbina, F. and H. Camacho, 1913. La zona megaséismica Acambay-Tixmadejé, Estado de Máxico, conmovida el 19 de noviembre de 1912. Bol. Inst. Geol. Méx. 32, $125 \mathrm{pp}$.

Utsu, T. and A. Saki, 1954. A relation between the area of aftershock region and the energy of main shock, $J$. Seism. Soc. Japan. 7, pp 233-240

Watts, A. W. and J. L. Bradbury, 1982. Paleoecological studies at Lake Patzcuaro on the West-Central Mexican Plateau and at Chalco in the Basin of Mexico. Quaternary Research 17, 56-70.

Wells, D. L. and K. J. Coppersmith, 1994. New empirical relationships among magnitude, rupture length, rupture width, rupture area, and surface displacement. Bull. Seismol. Soc. Amer. 84, 4, 974-1002.

Wesnousky, S. G. 1994. The Gutenberg-Richter or Characteristic Earthquake Distribution, Which Is It? Bulletin of the Seismological Society of America, 84, 6, 1940-1959.

Williams, W. D., 1980. Australian freshwater Life. In: The invertebrates of Australian Inland Waters. Mc. Millian, Melbourne.

V. H. Garduño-Monroy ${ }^{1 *}$, R. Pérez-Lopez², I. Israde-Alcantara ${ }^{1}$, M. A. Rodríguez-Pascua ${ }^{2}$, E. Szynkaruk ${ }^{3}$, V. M. Hernández-Madrigal ${ }^{1}$, M. L.García-Zepeda ${ }^{4}$, P. Corona-Chávez ${ }^{1}$, M. Ostroumov $^{1}$, V. H. Medina-Vega ${ }^{1,5}$, G. GarcíaEstrada $^{5}$, O. Carranza ${ }^{7}$, E. Lopez-Granados ${ }^{1}$ ${ }^{1}$ Instituto de Investigaciones Metalurgicas, Universidad Michoacana de San Nicolás Hidalgo, Cuerpo Académico Consolidadode Cienciasde laTierra, CiudadUniversitaria, Morelia, Michoacán, Mexico

${ }^{2}$ Servicio Geológico y Minero de España, Madrid, Spain ${ }^{3}$ Posgrado en Ciencias de la Tierra, Instituto de Geofísica, Universidad Nacional Autónoma de México, Mexico City, Mexico

${ }^{4}$ Facultad de Biología, Universidad Michoacana de San Nicolás Hidalgo, Ciudad Universitaria, Morelia, Michoacán, Mexico

${ }^{5}$ Maestria en Geociencias y Planificación del TerritorioInstituto de Investigaciones Metalurgicas, Universidad Michoacanade SanNicolás Hidalgo, Ciudad Universitaria, Morelia, Michoacán, Mexico

${ }^{6}$ Gerencia de Proyectos Geotermoelectricos, Comisión Federal de Electricidad

${ }^{7}$ Geociencias de Juriquilla, Universidad Nacional Autónoma de México, Juriquilla, Querétaro, Mexico

*Corresponding author:vgmonroy@zeus.umich.mx 